International Journal of Social Sciences and Humanities
Available online at http://sciencescholar.us/journal/index.php/ijssh
Vol. 2 No. 3, December 2018, pages: 173 179
e-ISSN: 2550-7001, p-ISSN: 2550-701X
https://doi.org/10.29332/ijssh.v2n3.227

\title{
Economic Vision for R \& D Projects of University
}

Elvia Mariana Cedeño Cedeño ${ }^{\text {a }}$, Antonio Vázquez Pérez ${ }^{\mathrm{b}}$, Gavin Antonio Toala Arcentales ${ }^{\mathrm{c}}$
Article history: Received 27 April 2018, Accepted: 30 August 2018, Published: 26 November 2018

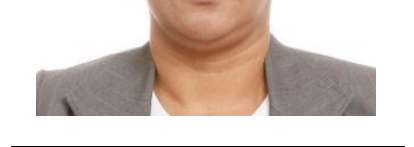

\section{Keywords}

articulation;

development;

financing sources;

research;

sustainable;

e-ISSN: 2550-7001, p-ISSN: 2550-701X ${ }^{\odot}$ Copyright 2018. The Author. SS Journals Published by Universidad Técnica de Manabí. This is an open-access article under the CC BY-SA 4.0 license

(https://creativecommons.org/licenses/by-sa/4.0/)

All rights reserved.

\section{Contents}

Abstract

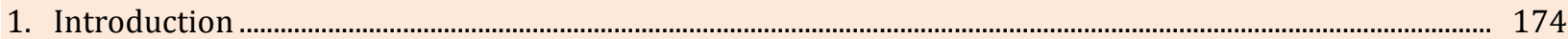

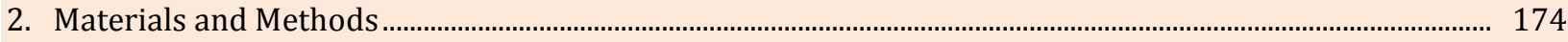

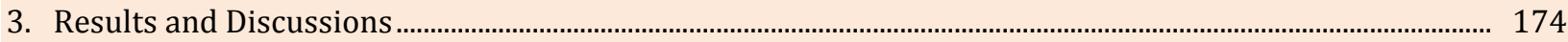

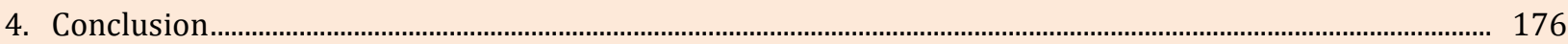

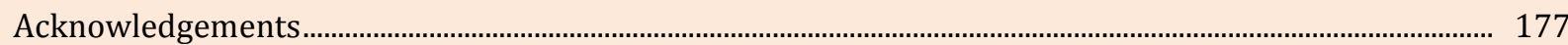

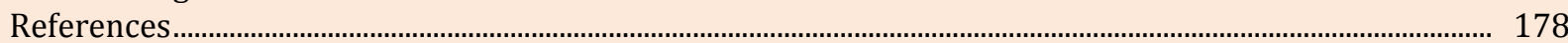

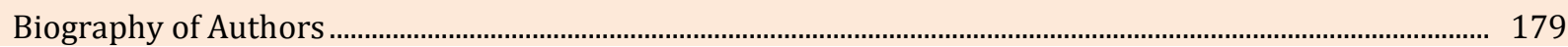

a Administrative department, Universidad Técnica de Manabí, Portoviejo, Manabí, Ecuador

b FCMFQ department, Universidad Técnica de Manabí, Portoviejo, Manabí, Ecuador

c FCMFQ department, Universidad Técnica de Manabí, Portoviejo, Manabí, Ecuador 


\section{Introduction}

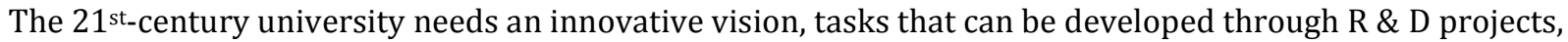
with its potential for scientific research that has strengths to carry out planning and development. At the university level, there is currently only one way of financing to complete the research interests that are currently being considered. The Technical University of Manabí (UTM) is located in an agricultural province, where its production focuses on guaranteeing a wide range of products, which play an important role in the basic basket of the Manabi society, markets that can be industrialized with the objective of increasing its use and adding added value. For this, the articulation of research projects that need external funding sources to be implemented is key.

The objective of the work is to point out the key to access external funding sources, which can contribute to the UTM in terms of supporting the development of R \& D projects and thereby strengthen the research capacity and infrastructure in the institution, achieving stimulating incentives in the establishment of mixed alliances that finance innovation.

\section{Materials and Methods}

In the investigation, the descriptive-explanatory method is deployed, since it is intended to obtain information about the articulation and management of R \& D projects in the university context. Explanatory because it is about establishing a study on the evolution of research as a method of scientific work and explaining the impact of project management on the role of the institution's teaching and research activity.

Research involves a process of analysis and understanding of reality and the problems associated with the articulation and management of projects; In this context, empirical methods will be used to investigate the problem, returning to the experience of other authors and work related to the subject studied, in order to carry out the preliminary analysis of the information and verify the effectiveness of the theoretical conceptions.

The traditional theoretical methods will be used, among them: The analysis-synthesis method in the study of bibliographic references; The historical-logical for the offering of precise thoughts related to the logic of the scientific-technical development in the topic of the articulation and management of R \& D projects in the university context, as well as the international experiences and of the country. The method of induction and deduction that allows from the presence of the content of the object of study to the elaboration of own conclusions, making it possible to offer the particularities and the proposed solutions.

\section{Results and Discussions}

\section{Characterization of the study site}

The UTM is located in the city of Portoviejo, capital of the province of Manabí, which is considered as the foundational territory of the nationality, because in its limits lies the Bay of Caráquez, which in the preColumbian era was the seat of the ancient city Indigenous of Carán and capital of the Kingdom of the Faces, an indigenous territorial entity that is considered the Cradle of the Ecuadorian Livestock, since this site is recognized as the point of arrival of large rafts occupied by the Nation Cará, elements that affirm in the literary work the History of the Kingdom of Quito, written by Father Juan de Velasco, which is perhaps one of the oldest texts in Ecuadorian Aboriginal History (Petroche, 1789).

The high house of studies is located at $1{ }^{\circ} 4^{\prime} 39^{\prime \prime} .22$ degrees south latitude and $80^{\circ} 45^{\prime} 58^{\prime \prime} .01$ degrees west longitude, very close to the center of the planet. This geographical location, the warmth of its climate, the nobility and kindness of its people, make the institution a permanent attraction for the development of community research projects, aimed at promoting the role of the university in solving problems socio-economic aspects of the territory.

The Alma Mater manabita was founded by Legislative Decree on October 29, 1952. Its founding objective is the integral formation of the human being so that it contributes to the development of the country and the achievement of social justice, strengthening of national identity in the pluricultural context of the country, to 
the affirmation of democracy, peace, the rights of people and communities, Latin American and global integration, as well as the defense and protection of the environment (Briones, 2004), (UTM, 2014).

Currently, the UTM's mission is to train academics, scientists and professionals responsible, humanistic, ethical and solidarity, committed to the objectives of national development, which contribute to the solution of the country's problems as a university of teaching and research, capable of generating and apply new knowledge, promoting the promotion and dissemination of knowledge and cultures, provided in the Constitution of the Republic of Ecuador (Constituent Assembly, 2008), with a vision focused on becoming a leading university institution, benchmark of higher education in the country, promoting the creation, development, transmission and diffusion of science, technology and culture, with social recognition, regional and global projection (Briones JF, 2004). In figure 1 you can see the geographical location of the province of Manabí.

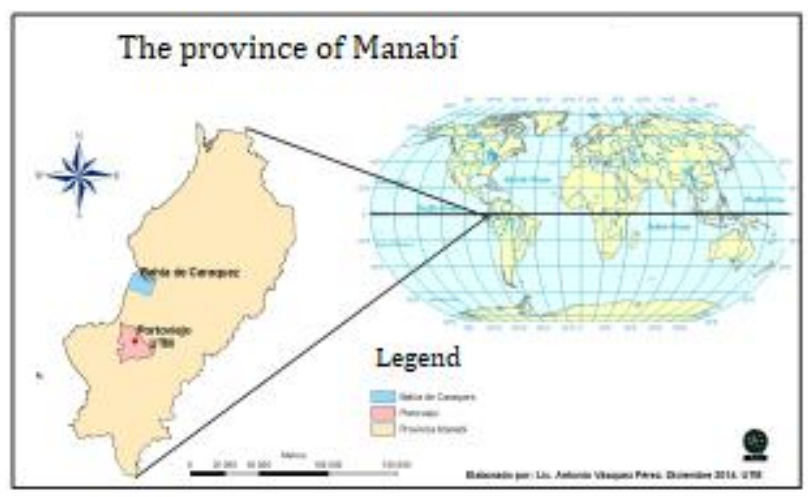

Figure 1. The Province of Manabí, UTM and Bahía de Caráquez. Source: (Vazquez, 2017)

At present, the Ecuadorian high school, is deeply committed to the destiny and plans of the nation, focused on achieving the training of professionals who, from their technical way of proceeding, can make the living letter of the political constitution of the republic (Constituent Assembly, 2008) and the challenges posed in the Production Code (National Assembly, 2010).

The University is a faithful watchdog of the transparency in administrative management that all state institutions that make up the public sector are obliged to observe, in the terms of article 118 of the political constitution of the republic (Constituent Assembly, 2008) and other entities indicated in article 1 of the Law itself and that is materialized through dissemination through an information portal or web page (UTM, 2014), as well as the necessary means available to the public implemented in the institution itself, on the minimum updated information, which for the purposes of this Law is considered mandatory (Briones, 2004).

The UTM has full powers to organize itself within the provisions of the Constitution of the Republic of Ecuador, the Organic Law of Higher Education, its Regulations, other related laws, the Organic State and the regulations issued to structure the organization of the institution (Briones, 2004).

The university population is approximately 12,435 of which 1358 correspond to managers, teachers, service personnel, workers and students. From the teaching point of view, the center has eight faculties and two educational units. The direction is carried out by the Rectorship which has six departments that guarantee the activity of direction and control, as well as other structures of insurance and services. The research work is attended centrally by the Research Department, which has the mission of advising and coordinating the research activity throughout the university.

From ancient times, man was already concerned about the fundamental questions of reality that affected in a special way his existence: the origin, nature, history and purpose of beings and among them of man himself, but the response he tried to give these questions was not of a rational order, as philosophy will do later, but of

Cedeño, E. M. C., Pérez, A. V., \& Arcentales, G. A. T. (2018). Economic vision for $R \&$ D projects of university. International Journal of Social Sciences and Humanities, 2(3), 173-179. https://doi.org/10.29332/ijssh.v2n3.227 
magical and mythical-religious nature, he built a knowledge prior to philosophy which philosophers usually call pre-philosophical knowledge (Ramón, 2007).

Man is the only being endowed with a superior intelligence that allows him to investigate the reason for the events and phenomena that occur around him. During prehistory it began with a very simple and slow investigative process; but very important for the development of the humanity since its first inventions constituted a very big step and transcendental for the later development (Hugo, 2000).

For its part, research beyond whether it is scientific or not is a process by which they face and solve problems in a planned manner and with a specific purpose. One way to classify different types of research, in general, is based on their purpose or purpose since different purposes correspond to different types of research (Cazau, 2006).

Research today has acquired an unusual importance, there is almost no transcendent human activity that does not have a scientific type of research as its antecedent (Hugo, 2000). In practice, all branches of the economy and services are being addressed through a scientific research methodology. Currently, researchers from around the world are engaged in a constant search for solutions to the problems that afflict humanity. An endless search, because if there is a solution, then more and more problems that obey new human aspirations will appear because the happiness of man on earth is not achieved by just solving one, as the problems are resolved. problems appear others that require to be solved (Hugo, 2000).

Traditionally, the universities of Ecuador are characterized as teaching institutions, where the scientific research process does not receive the attention and support it requires in order to achieve the proposed results. At the institutional level, there is not a sufficient budget dedicated to promoting research management in universities and to this must be added the scarce research culture that university professors possess regarding research methodology and project management. All this leads to the universities projecting little visualization of the opportunities for the articulation of projects, situation that must be reversed if one wants to advance in the option to achieve a superior education of excellence according to the current international standards.

\section{Keys to request funding for a project}

Today's society lives a complex situation, forced to transform the traditional model of development and assume the sustainable production of goods and services as a paradigm of modern society. For this, a constant process of technological updating must be assumed, which can be done through the articulation and development of various research projects, where institutions with their knowledge potential can play a key role. But this research effort would be impossible without an adequate policy and sufficient financing coverage, for which the UTM is not prepared, nor does it have reliable sources of funding that will allow them to develop project management based on their own interests and priorities.

The financing of projects will serve to generate knowledge and develop priority lines of work for the institution such as social innovation, public function, training innovation, territorial studies, and administrative innovation. The following are the routes for requesting financing for a project. Carry out the search for calls that fit with the theme of the project to be carried out; study punctually the call, the documents that are requested and requirements established by the granting body; be sure that the proposal fits with the priorities of the funding body or entity; point out the limit of the financing amount; obtain information on the management and operation of the agency that will provide the financing; with the own idea and the collected information, the conceptual idea of the project is developed starting from the deployment of the punctual planning of the investigation until obtaining the final results; determine what requirements and additional documents are needed and; review and clarify the project well $v$ Verify if the objectives can be reached and test the hypothesis with the time and resources that have been planned, verify if the proposal meets the requirements of relevance of the project; Approach and method; innovation and; resources and budget.

Keep in mind that if you want to achieve the proposed funding you must combine a good methodology and the argument necessary to meet the rules and requirements of the financier of fora that the idea is understood quickly by an evaluator and explained briefly to other evaluators. 


\section{Conclusion}

The work provides an analysis related to the research activity in the Ecuadorian universities and has allowed to offer the required keys for the application of financing of research projects to the granting agencies, so that it constitutes a working guide for the professors and researchers of the UTM, in order to invigorate the work of scientific research in the institution.

\section{Acknowledgments}

The authors would like to thank the reviewer of the IJSSH as well as the editor of the IJSSH for their consideration, support, valuable time, and advice. 


\section{References}

Briones J.F. (2004). Anales de una universidad en marcha. Segunda época, Impresa en el mes de junio de 2004, en los talleres de la imprenta universitaria de Porto Viejo.

Cazau, P. (2006). Introducción a la investigación en ciencias sociales. Buenos aires, 27.

Constituyente, E. A. (2008). Constitución de la República del Ecuador.

de la Producción, C. O. (2010). Comercio e Inversiones, de la Asamblea Nacional-registro oficial N 351. Diciembre del, 30.

Hugo, G. (2000). Investigación Científica. Ediciones Abya-Yala. Quito. Ecuador, ISBN: 9978-04-641-0. Derechos de autor 014404 octubre 6/2000.

Pérez, A. V., Briones, V. V., Viteri, C. G. V., \& Gámez, M. R. (2017). Iberoamerica in Network, GIS \& TIC. International Journal of Social Sciences and Humanities (IJSSH), 1(3), 108-117.

Petroche. (1789). Historia del reino de quito. Documento en PDF. 4ta Edición 2008, Disponible en:

Ruiz Ramón. (2007). Historia y evolución del pensamiento científico. ISBN-13: 978-84-690-6369-9. № Registro: $07 / 44311$.

UTM. (2014). ¿Quienes somos? História universitaria. Consultado el 12 de MAYO de 2016. 


\section{Biography of Authors}

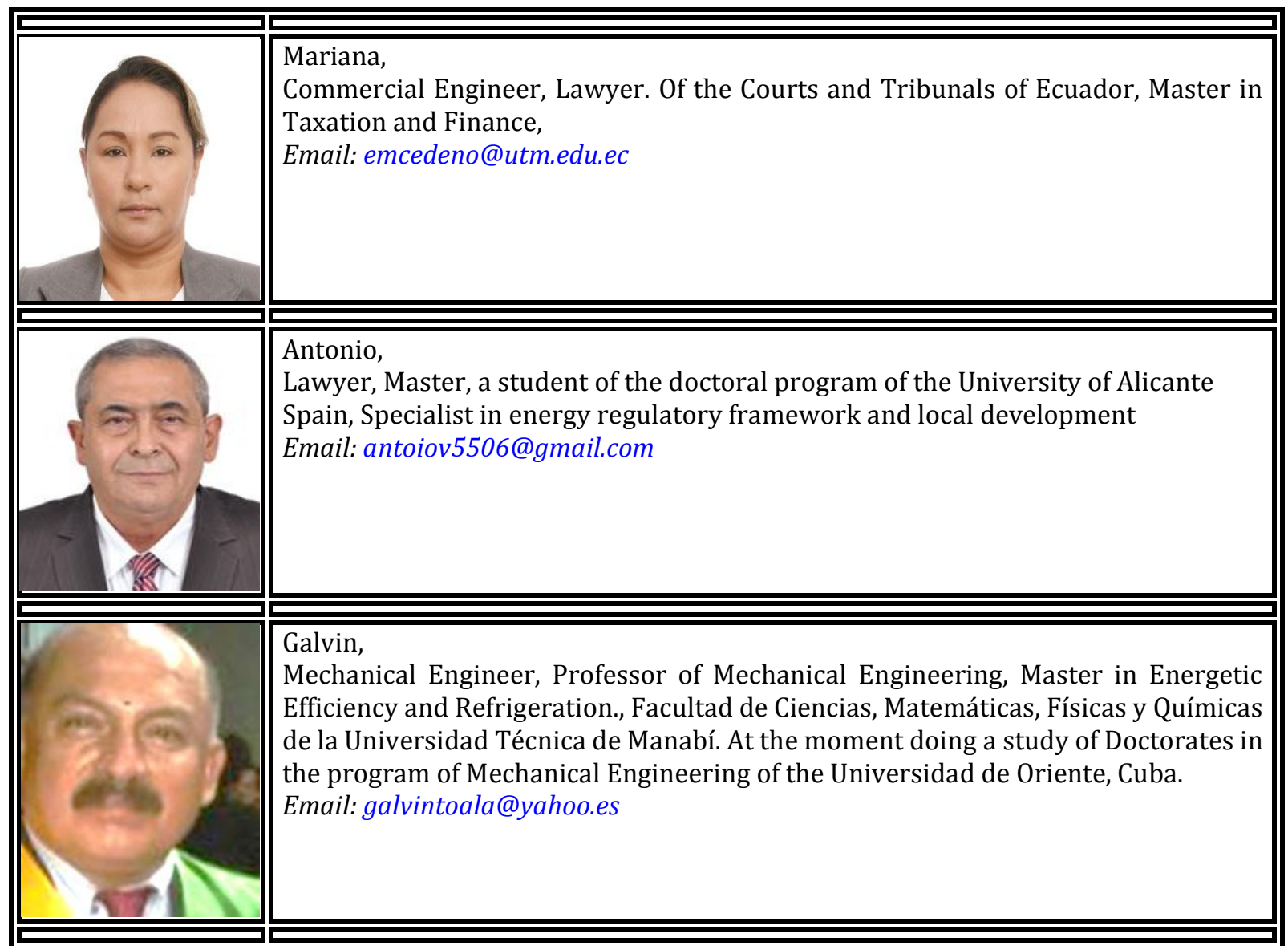

Cedeño, E. M. C., Pérez, A. V., \& Arcentales, G. A. T. (2018). Economic vision for R \& D projects of university. International Journal of Social Sciences and Humanities, 2(3), 173-179. https://doi.org/10.29332/ijssh.v2n3.227 